\title{
Correction to: Detect tissue heterogeneity in gene expression data with BioQC
}

Jitao David Zhang ${ }^{1 *}$ (D, Klas Hatje ${ }^{1}$, Gregor Sturm¹, Clemens Broger ${ }^{1,3}$, Martin Ebeling ${ }^{1}$, Martine Burtin², Fabiola Terzi ${ }^{2}$, Silvia Ines Pomposiello ${ }^{1}$ and Laura Badi ${ }^{1}$

\section{Correction}

After the publication of this work [1], a mistake was noticed in the Eq. 1. Given an $m \times n$ expression matrix with $m$ genes and samples of $n$ tissues, the correct definition of the Gini index for gene $i$ is:

$$
G_{i}=\frac{1}{n}\left(n+1-2\left(\frac{\sum_{j=1}^{n}(n+1-j) x_{i j}^{\prime}}{\sum_{j=1}^{n} x_{i j}^{\prime}}\right)\right),
$$

where $x_{i j}^{\prime}$ is the $j$ th value in the non-descending ordered vector of $x_{i}(i=1, \ldots, m, j=1, \ldots, n)$. In the original version of the manuscript, the variable $j$ in the parentheses of the nominator was erroneously written as $i$.

The authors apologize for the mistake and thank Mr. Tao Fang for pointing out this mistake.

\begin{abstract}
Author details
${ }^{1}$ Roche Pharma Research and Early Development, Pharmaceutical Sciences, Roche Innovation Center Basel, F. Hoffmann-La Roche Ltd, Grenzacherstrasse 124, 4070 Basel, Switzerland. 'Institut Necker Enfants Malades, Inserm U1151, Université Paris Descartes, Paris Hôpital Necker Enfants Malades, 149, Rue de Sèvres, 75015 Paris, France. ${ }^{3}$ Present Address: Peter-Rot-Strasse 84, 4058 Basel, Switzerland.
\end{abstract}

Received: 16 July 2018 Accepted: 16 July 2018

Published online: 30 July 2018

\section{Reference}

1. Zhang JD, et al. Detect tissue heterogeneity in gene expression data with BioQC. BMC Genomics. 2017;18:277. https://doi.org/10.1186/s12864-017-3661-2.

\footnotetext{
* Correspondence: jitao_david.zhang@roche.com

${ }^{1}$ Roche Pharma Research and Early Development, Pharmaceutical Sciences, Roche Innovation Center Basel, F. Hoffmann-La Roche Ltd, Grenzacherstrasse 124, 4070 Basel, Switzerland

Full list of author information is available at the end of the article
}

(c) The Author(s). 2018 Open Access This article is distributed under the terms of the Creative Commons Attribution 4.0 International License (http://creativecommons.org/licenses/by/4.0/), which permits unrestricted use, distribution, and reproduction in any medium, provided you give appropriate credit to the original author(s) and the source, provide a link to the Creative Commons license, and indicate if changes were made. The Creative Commons Public Domain Dedication waiver (http://creativecommons.org/publicdomain/zero/1.0/) applies to the data made available in this article, unless otherwise stated. 